\title{
On Vocalic* Variations in Portuguese Dialects
}

\author{
Irene Maria Ferreira BLAYER \\ Associate Professor / Brock University
}

\section{Context}

Under the rubric of standard Weinrich (1954, p. 396) includes, among other notions, those of 'socially acceptable' or 'average' or 'typical'. For Portuguese linguists the main criterion for a model to represent standard language has always been the speech modality of the cultured or urban people. There is no agreement, however, over whether the speech of Lisbon or that of Coimbra should set the norm. In an article reviewing the position of early Portuguese linguists regarding the interpretation of what is the Portuguese padrão (standard), Boléo (1946) expresses that Gonçalves Viana (1892) and José Pedro Machado (1940) shared the conviction that it is the speech of the cultured parlance of Lisbon that is considered as the standard, as opposed to that of Coimbra, which was the choice of Oliveira Guimarães (1927) as well as Boléo (1946, p. 11-12).

The notion that the speech of Coimbra represented the best model of speech in Portugal had been postulated and defended already in the seventeenth century. Vasconcelos (ed. 1970, p. 54) quotes a passage by Dom Francisco Manuel de Mello in Apólogos dialogaes (ed. 1721, 261 62) which reads as follows:

\footnotetext{
${ }^{1}$ Both the vowel and the diphthongal systems constitute a vocalic system. This is an important distinction in the diachronic analysis of the Romance languages since the diphthongal system acts at times on the vowel systems through constant pressure of monophthongization, -as it occurs in the speech of São Miguel-, as well as diphthongization, etc.
} 
se cá entre nós dissessemos se fallava mais elegante em Coimbra, que em outra parte, não mentiriamos, sendo alli o coração e alma das sciencias que se ensinam e aprendem.

Vasconcelos, however, questions this view when stating: "Chacun prèche pour son saint, selon ses prédilections naturelles” (p. 54). Boléo’s argument supporting his preference for the speech of Coimbra to be accepted as the norm for the standard language is based on the fact that the speech of the capital does not necessarily reflect a norm for the best pronunciation. He points out that, contrary to the linguistic situation in Spain, France and England, where the role of the capital was unquestioned in the spread of a language norm, other countries, such as Italy and Germany do not exhibit the best speech characteristics based on the speech of their capitals. He remarks:

Ora no estado actual dos nossos conhecimentos, se é legítimo defender, como norma ortoépica, a pronúncia da capital, por motivos de ordem política e social, não é menos defender a de Coimbra, por motivos sobretudo lingüísticos (1946, p. 12).

It is not within our scope to deal more extensively with the reasons, controversies and theories that guided Portuguese linguists to have common or opposing viewpoints in regard to whether Coimbra or Lisbon represents the standard language. It is important to recognize that, in spite of any argument regarding location, what prevails, and is shared by the opinions (Cuesta and Mendes da Luz, 1980; Vasconcelos, 1970; Boléo, 1942; Viana, 1891) on this subject is that the language of the cultured people is the main criterion used in the selection of a norm representing the standard language. In regard to this view Vasconcelos (ed. 1970, p. 15) writes: 
Jusqu'au XII ${ }^{\mathrm{e}}$ siècle, la langue portugaise n'existait que comme langue parlée; au moins on ne connaît pas, antérieurment à cette époque, de documents entiérement écrits en portugais. Naturellement, les classes les plus instruits, comme celle des clercs, employent, par opposition au peuple, des formes considérées comme plus choisies; mais ce ne fut que lorsqu'on commença à écrire le portugais, et surtout depuis que cette langue devint proprement littéraire XIII $^{\mathrm{e}}$ et $\mathrm{XIV}^{\mathrm{e}}$ siècles), que l'on peut distinguer clairement deux courants, l'un populaire, et l'autre érudite.

For Vasconcelos, it is this literary language that exhibits distinct features from the language used in the north of Portugal (Minho), the centre (Beira) and the south. It is clear that there is a norm for the standard language and it is against this that other speeches (within the country) exhibit variations. We believe that there is no valid reason for assuming a value judgement suggesting that one region speaks 'better' than another. This is an oversimplification.

In this study we are not guided by the presuposition of a 'better' speech when outlining the phonetic characteristics of Standard Portuguese, but our intent is to establish a model of standard language against which to evaluate the phonetic characteristics of the regional variants, and that will bear upon our research.

Here we are following the preference of those linguists who accept the speech of Lisbon as the model for lingua padrão (Bonaparte, 18801881, p. 23-41; Viana, 1892, p. 29-98; Sweet, 1882-1883-1884, p. 203-237; Barbosa, 1983, p. 21; and others).

\subsection{Dialect Variations of Portuguese}

Portuguese on the whole represents a linguistic community with a distinctly unified pattern of speech. Only the speech of Miranda, Riodonor and Guadramil, in the northeast of Portugal, digress considerably from

SIGNUM: Estud. Ling., Londrina, n. 5, p. 77-106, dez. 2002 79 
the norm; they are more akin to Leonese than to Portuguese, ${ }^{1}$ otherwise, the diffferences from one region to another are not acute: "não há, como em muitos outros países, duas normas linguísticas que se oponham e influam uma sobre a outra. (Helmut Lüdtke, 1954, p. 216). This being the case, for example, in Italy or in Germany. Given that the differing features found in these regions often do not map on to predictable boundaries, it is difficult to speak of dialects of Portuguese in the strict sense of this term. In referring to the linguistic situation in Portugal, Barbosa (1983, p. 23) affirms:

On prend même le pretexte d'une telle uniformité pour affirmer que le portugais ne connait pas de $<<$ dialectes $>>$, mais seulement des $<<$ parlers régionaux $>>\ldots$ Nous dironts toutefois que, si l'on prend le mot $<<$ dialecte $>>$ dans le sens qui est le sien lorsque l'on parle de $<<$ dialecte de New York $>>$, de $<<$ dialecte de Boston $>>$, etc., il y a des dialectes portugais sur le continent européen...

Within this general pattern, however, there are regional varieties with a number of phonetic traits of some importance. On the basis of such differences, Portuguese linguists have proposed a number of division of the Portuguese spoken in mainland Portugal. Each linguist, however, has applied his or her own criterion of the terms dialecto, subdialecto, codialecto, variedade, or falar (Vasconcelos, 1893-1897; 1901; Paiva Boléo and Maria Helena Santos Silva, 1959-1962; Pilar Vázquez Cuesta and M. Albertina Mendes da Luz, 1980; Lindley Cintra, 1983).

\footnotetext{
${ }^{1}$ For information on these dialects see José Leite de Vasconcelos, Estudos de Philologia Mirandesa (Lisboa, 1900-1901); Mapa Dialectológico (Lisboa, 1893-1897); José Herculano de Carvalho, "Porque se falam dialectos leoneses em terras de Miranda?" RPF, (1952, p. 265-291; republished in Estudos linguísticos, (Lisboa, 1964, p. 39-60; Cuesta and Mendes da Luz (1980).
} 
Vasconcelos (1893-1897, 1901) divided Portugal into three major dialect areas: ${ }^{2}$ North comprising the provinces of Minho, Douro and Trásos-Montes with the dialectos interamnense and trasmontano; Centre including the provinces of Beira Alta and Beira Baixa with dialecto beirão; and South which comprises Estremadura, Ribatejo and Algarve with the dialecto meridional. Each dialecto in this taxonomy is subdivided into subdialectos.

Paiva Boléo and Maria Helena Santos Silva (1959-62) use the term falar (speech) in their division. ${ }^{3}$ They distinguish between six main falares: (1) minhoto, (2) trasmontano, (3) beirão, (4) Baixo Vouga e Mondego, (5) Castelo Branco e Portalegre, and (6) meridional. They further divide each falar into variedades and subfalares. ${ }^{4}$

Pilar Vázquez Cuesta and M. Albertina Mendes da Luz (1980) use the terms falar and variedade and they prefer to distinguish between three main areas, geographically defined as follows: a) the north, a conservative area (which includes the provinces of Minho, Douro and Trás-os-Montes); b) the centre, a transitional area betweeen the north and south (including Beiras); and c) the south (which includes Ribatejo, Alentejo and the

\footnotetext{
${ }^{2}$ Vasconcelos (1929, p. 796) says in reference to the term dialecto: “... com a expressão dialecto não quero significar um conjunto uniforme, pois que dentro de cada um desses conjuntos há ... variações..."

${ }^{3}$ The term dialecto is also used by these authors but with a wider scope, and specifically it applies to guadramilês, rionorês, mirandês spoken within the Leonese area.

${ }^{4}$ Within each category, these authors distinguish between "traços gerais, comuns a uma região; traços limitados a uma sub-região; traços comuns a uma zona limítrofe." This classification appears to be controversial according to Cintra (1983, p. 132-136) who argues as follows: "Os 'traços gerais' seleccionados para caracterizar um falar, são, na minha opinião, de muito desigual valor distintivo. Por vezes encontram-se simultaneamente em regiões muito diversas, ao mesmo tempo que nem sempre são, como em alguns casos o revelam os próprios autores, realmente 'gerais' na região a caracterizar. Por outro lado, não foram considerados entre esses 'traços gerais' alguns cuja relevância é indiscutível e foi reconhecida pelos estudiosos anteriores; entre eles estão algumas características que são sentidas como muito típicas...Quanto aos traços 'limitados a uma sub-região' e aos 'comuns a uma zona limítrofe'... muitos deles se reencontram noutras regiões apesar de parecer evidente que, em princípio, este facto deveria ter desaconselhado a sua selecção. "
} 
Algarve). Cintra (1983, p. 139) points out that this classification excludes minor areas within the major linguistic regions. He wrote:

Também me parece dificilmente defensável o isolamento em Portugal de um Centro, em relação a um Norte e a um Sul dialectais: as autoras não indicam na obra - e creio que não poderiam realmente indicar - qualquer conjunto de traços ou até mesmo qualquer traço importante (fonético ou morfosintáctico) que pudesse servir para separar esta zona central, simultaneamnte, da setrentional e da meridional. A distinção feita pelas autoras, tem sem dúvida, uma base mais propriamente geográfica que linguística.

The most recent classification, and the one that we follow closely in our study, is Lindley Cintra's (1983, p. 152-54). Taking into account the dialects of Galicia, he has proposed a tripartite dialect ${ }^{5}$ division: a) dialectos galegos; b) dialectos portugueses setentrionais in two groups, those of Alto-Minho and Trás-os-Montes, and those of Baixo-Minho, Douro and Beira Alta, and c) dialectos portugueses centro-meridionais comprising those of centro-litoral (estremenho-beirões) and those of centro-interior e sul (ribatejano-baixo-beirão, alentejano-algarvio). Cintra's reason for this division is as follows:

... por admitir como necessária uma consciente e voluntária tentativa de simplificação, assente numa selecção prévia e numa hierarquização de um número relativamente pouco elevado de traços fonéticos entre os muitos de que nos podemos servir para caracterizar os dialectos ou falares portugueses. (1983, p. 140-141)

\footnotetext{
${ }^{5}$ For Cintra dialecto means "...toda e qualquer variedade regional de uma língua, seja qual for o seu grau de afastamento em relação ao padrão.” (1983, p. 141)
} 
In general terms one can speak of the falares of the North ${ }^{6}$ and of the South respectively (Cintra, 1983, p. 142). What is not clearly defined, though, are the isoglosses that separate each group. In reference to this, Boléo (1951, p. 35) tells us “...torna-se muito difícil establecer, sob o aspecto linguístico, onde acaba o Norte e começa o Sul.”

\section{Vocalic dialect variations in Portuguese: Mainland Portugal}

The region of Beira Baixa and Alentejo which comprises the urban centres of Castelo Branco and Portalegre is characterized by a profound alternation of the whole vocalic system, especially that of the stressed vowels. The most distinct feature of this zone is the change of $/ \mathrm{u} />[\ddot{\mathrm{u}}]$, frequently registered in some localities in Portalegre, Moção, Nisa, Castelo Branco, Idanha-a-Nova, Oleiros, and Covilhã.

Lüdtke (1957, p. 106-110) studied the vowel system of this region, zone 2 , and saw a chain reaction as follows: e $>\varepsilon>a>0>0>u>\ddot{u}$. And he establishes two vocalic systems both with fronted /e $\varepsilon$ o/. The [ü] pronunciation is not confined to this area, but is widespread in zone 3, in the area known as Barlavento do Algarve (Cintra, 1983, p. 157-58). ${ }^{7}$ Leite de Vasconcelos (ed. 1970:83) saw it as an area feature and delimitates it as follows:

\footnotetext{
${ }^{6}$ The Portuguese of the North has neutralized the distinction /v/ and /b/ in favour of the latter, as in Galician and Castilian; has kept the distinction between the apico-alveolars /s z/ and the reflexes of the medieval $[\mathrm{ts}]$ and $[\mathrm{dz}]$ as predorso-dentals /s z/; has maintained the old $\left[\mathrm{t} \int\right]$, grapheme ch. Standard Portuguese, as is known, has one pair of sibilants, predorso-dental $/ \mathrm{s} /$ and $/ \mathrm{z} /$, having merged the alveolars with these.

7 The same geographic delimitation for [ü] is also reiterated by Cuesta and Mendes da Luz (1980:61), and in regards to the intensity of this vowel they conclude that "A palatalização do u pode ser mais ou menos intensa e não se dá em posição átona: maduro (ü) mas madurar (u). Others also remark that the French [ü] is a feature of the speech of Vila do Bispo (Nunes, 1902, p. 34; Lüdtke, 1957, p. 95-112; and Maia, 1975-78, p. 58).
} 
... de Fundão et Sertã (Beira Baixa) jusqu'à Portalegre (alto Alentejo), et qui comprend quelques territoires de l'Estrémadure (Alvaiázere, Paialvo), l'u de la langue littéraire devint ü: rüa, müro, düas. Ensuite le phénomène apparait dans l'Algarve (Barlavento), où je l'ai observé à Lagos et à Vilado-Bispo: üm, lüa, viüva. Il est probable que l’ü existe aussi dans certains endroits compris entre ces zones.

Hammarström (1953, p. 51-52 and passim) on the other hand, disputes the délimitation of this vowel in western Algarve and he emphasizes that its occurrence is not "si limitée que les dialectologues semblent l'indiquer, mais peut être constatée dans une grande partie de la province" (p. 146). He outlined the following chain reaction in the vocalic development (1953, p. 73): (ei $>$ e) e $>\varepsilon>a>0>0>$ u $>$ ü.

Cintra (1983) questions Hammarström's delimitation of [ü] in this speech, and he remarks: "...é uma fonte a manejar com cuidado, por razões metodológicas" (p. 157, note 59). He confirms, though, that the presence of $[\ddot{u}]$ is, however, an important linguistic factor setting apart the western Algarve from eastern Algarve (p. 137, note 33). ${ }^{8}$

The Portuguese of the North has maintained the diphthong [ow] also pronounced as [aw] (in the south [ow] is monophthongized with different results). The diphthong /ow/ is kept in the North as [ow], pronounced in some areas as [aw]. Vasconcelos speaks of the existence of a variant $[\ddot{o w}],-$ also occurring in the Azorean speech- in north of Trás-os-Montes, and part of Entre Douro e Minho, and possibly in part of Beira (Esquisse). For Cintra (1983, p. 43) has noted [öw] as typical of the north and centre of Trás-os-Montes.

The diphthong /ow/ is reduced to [o] in the south commonly pronounced in the third person preterite ending ou, as in tirou. Otherwise

\footnotetext{
${ }^{8}$ In Sagres and Vila do Bispo the nasal counterpart also palatalizes (Hammarström 1953, p. 53, 159; Maia, 1975-78, p. 58-59).
} 
it alternates with [oj] in all regions, and in fact in some words [oj] is more common. Cintra (1983, p. 44) tells us: "São muito mais complexos e difíceis de descrever os resultados de qualquer tentativa de localização geográfica no território português da variante oi.” (1983, p. 43).

Words such as ouro, cousa, dous, touro, outro outeiro are either pronounced with [ow] or with [oj] (Cintra, 1983, p. 44). It appears that this alternation does not reflect the dialectal preference in the pronunciation of certain terms (touca as toica and ouvir as oivir) as Vasconcelos suggests, nor that [oj] reflects the popular speech or [ow] the literary. Cintra states that

não há nenhum falar português em que [oi] não exista, a par de [ow] ou do $[\mathrm{o}]$ proveniente da sua monotongação [...] ao que há é falares em que [oj] não só se manteve nos casos em que era etimológico, mas aparece em grau maior ou menor nos casos em que se esperaria [ow] ou [o].

In the insular speech of the Azores [oj] is common for [ow] in the islands of Flores, Corvo, São Jorge, and Santa Maria. The variant [öj] appears in São Miguel, Flores, Corvo, Santa Maria. ${ }^{9}$ This is also found in the speech of the island of Porto Santo, as in outra [ojtra], ouvir [ojvir], roubo [rojbu] (Monteiro, 1948-50, p. 95).

In some speech areas of Beira Baixa and Alto Alentejo /ow/ not only monophthongizes but it is also pronounced as [ö] (Cintra, 1983, p. 46; Lüdtke, 1957, p. 110). Cintra explains that the [ö] resulting from /ow/ occurs at the same time as the monophthongization of /ow/ as [o], and that it does not reflect a variation in the pronunciation of $[\mathrm{o}]$ from an earlier monophthongization. He concludes:

A monotongação de ou em $\ddot{o}$ envolve teoricamente um grau intermidiário de palatalização do $o$ inicial do ditongo (eu por ou), que nos é perfeitamente conhecido da fonética histórica francesa - em que, como

${ }^{9}$ For details see Blayer 1992.

SIGNUM: Estud. Ling., Londrina, n. 5, p. 77-106, dez. 2002 
se sabe, o o longo em sílaba aberta, através das fases ou e eu, e acompanhado, a partir de certa altura, pelo ditongo ou de outras origens, se transforma precisamente no $\ddot{o}$ que vamos encontrar nesta região portuguesa. (1983, p. 52-53).

On the other hand, the Portuguese of the South, is characterized by the monophthongization of the diphthong / ej/, which occurs in Alentejo, Algarve and in western Estremadura, and he adds:

A cidade de Lisboa forma, como é sabido, um enclave conservador nesta área de reducção...É evidente que, mesmo depois dos progressos recentes, estamos longe de nos encontrar definitivamente informados sobre o traçado das isófonas respeitantes à monotongação dos ditongos (Cintra, 1983, p. 40).

According to Teyssier the demarcation line between [ej] and [e]:

... est une ligne qui part de la côté Atlantique aux environs d'Óbidos, descend vers le sud en englobant Lisbonne, remonte vers le nord-est...et rejoint la frontière espagnole au nord-est de Castelo Branco. Il y a donc encore une fois un Sud (zone d'innovation) et un Nord (zone de conservation). Mais la grande différence avec les limites dialectales précédentes, c'est que cette fois-ci Lisbonne est comprise dans la zone $d u$ Nord... (1980, p. 79-80)

The monophthongization of / $\mathrm{ej} /$ is not conditioned by the consonant, it may or may not be preceded by a palatal consonant as in the examples that follow: cadeira, azeite, ameixa, ribeira, cereja (Boléo and Silva, 1961, p. 100-101; Hammarström, 1953, passim; Cuesta and Mendes da Luz, 1980, p. 64-65; Maia, 1975-78, p. 72). When the diphthong / ej/ is the result of $[\mathrm{e}]$ before $/ \int 3 \mathrm{n} K /$ as in vejo, Alentejo (corresponding to Standard

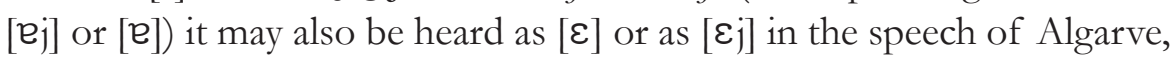


however, the most general pronunciation is as [e] (Hammarström, 1953, p. 131). In the third person singular of the preterit (jantei, almocei) this diphthong often corresponds to [i] in Alentejo (Boléo and Silva, 1961, p. 101; Maia, 1975-78, p. 72). Other cases of monophthongization are also recorded in the speech of this region.

In the western region of the Algarve, the stressed / aj/ is reduced to [a] (and/or it presents various degrees of velarization in the localities where stressed $/ a /$ is velarized). This reduction occurs when in the final

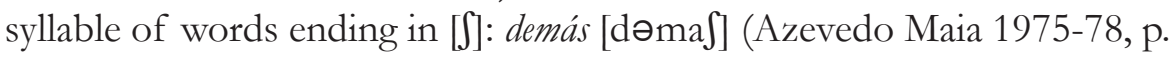
69; Hammarström, 1953, p. 71, 81, 166). In the same conditions, /oj/ is reduced to [o], and to [ö], which is found as well in the speech of São Miguel (Azores) as well as in other islands of the Azores, and in Madeiran:

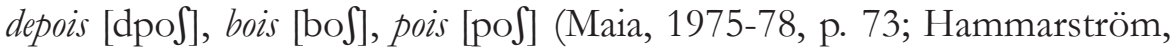
1953, p. 166; Lüdtke, 1957, p. 110; Cintra, 1983, p. 43). The diphthongs / $\mathrm{ew} /$ or $/ \varepsilon \mathrm{w} /$ in stressed or unstressed positions, or when in proclisis may correspond to [e] in the speech of Alentejo (Boléo and Silva, 1951, p. 101) and the Algarve (Maia, 1975, p. 78-37; Hammarström 1953:passim). ${ }^{10}$

2.1 Within the areas of North and Centre-South, Cintra (1983, p. 151159) refers to three zones with distinct identities: Zone 1 in the north (the region of Baixo Minho and Douro Litoral which has the urban centre Porto); Zone 2 in the centre-south (the region of Beira Baixa and Alentejo, comprising the urban centres of Castelo Branco and Portalegre); and Zone 3 in the south (the speech of a small area in west Algarve, also known as Barlavento do Algarve).

\footnotetext{
${ }^{10}$ Other examples are in unstressed position, the diphthong / aw/, as a result of word-formation (раи / pauzinho), or in contact with another word (man tempo, pau ferro), is reduced to [a] in some areas of the Algarve (Maia 1975-78:69). Also in this speech the unstressed / uj/ may correspond to [u]: descuidar [?kudar], cuidar[kudar] (Maia 1975:78-37; Vasconcelos ed. 1970: 90). The reduction also affects the nasal diphthongs in stressed and in syllable-final position (Maia 197578:69; Cuesta and Mendes da Luz 1981:65). This feature prevails mainly in Baixo Alentejo and the Algarve (Cuesta and Mendes da Luz 1981:65; Hammarström 1953:61,168) In insular speeches, these traits are recorded in the Azores and Madeira and Porto Santo.
}

SIGNUM: Estud. Ling., Londrina, n. 5, p. 77-106, dez. 2002 
a) Zone 1 is characterized by the diphthongization of the stressed closed /e/ as [je], and of the stressed closed /o/ as [wo] or as [wa] (Cintra 1983, p. 153). Cuesta and Mendes da Luz give us the following information:

... (desde o Porto a Guimarães, Ponte de Lima, Barcelos e Póvoa do Varzim) produz-se a curiosa ditongação incipiente de (ê) e (o) — tanto fechados etimologicamente como por metafonia- em (jê) (wô): pera (jê), menos (jê), poço (wo), porto (wo). Regista-se também esta ditongação quando se trata de $(\hat{e})$ e $(\hat{o})$ mas o ditongo leva então a vogal mais aberta: tierra (jê), quero (jê), morta (wo) ... (1980, p. 61)

In addition, they also state (p. 61) that Schürr (1956) had thought that the diphthongization occurring in Douro Litoral and Minho proved 'uma primitiva ditongação condicionada por metafonia em toda a România,' but they point out that Dámaso Alonso (1962, p. 39) had called attention to the fact that a good number of cases of diphthongization of /o/ registered in Porto are after a labial or a velar: $p^{\mathrm{w}}$ orto, $c \mathrm{w}^{\mathrm{w}}$ odia, $c \mathrm{w}^{\mathrm{w}}$ onde, $p^{\mathrm{W}}$ onte, $f \mathrm{w}$ onte, $m \mathrm{~m}^{\mathrm{W}}$ onte, desc $\mathrm{w}_{\text {onte, }} p^{\mathrm{w}}$ ois. In this connection, note also the examples

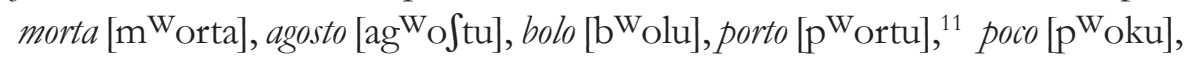
poço $\left[\mathrm{pw}^{\mathrm{O}} \mathrm{Osu}\right]$; conto $\left[\mathrm{k}^{\mathrm{W}} \tilde{\text { õtu}}\right]$ (Boléo and Santos Silva, 1951, p. 95; Cuesta and Mendes da Luz, 1980, p. 61; Santos Silva, 1961, p. 313). The following cases exemplify the diphthongization of /e/: neve [njeßə] / [njeßə], sete [sjetə] / [sjetə], ${ }^{12}$ or the nasal counterpart (Santos Silva, 1961, p. 311312). In these examples the stressed vowel is before or after a dental, or both.

\footnotetext{
${ }^{11}$ Both bolo and porto are also heard with [we]: [ $\left.\mathrm{b}^{\mathrm{w}} \mathrm{elu}\right]$, [ $\left.\mathrm{p}^{\mathrm{w}} \mathrm{ertu}\right]$.

${ }^{12}$ Also appearing in this speech is the pronunciation of [e] as [ej] and [ew] (Santos Silva, 1961, p. 312).
} 
Diphthongization of both /o/ and /e/, which occurs after labials and velars respectively, appears in other speech areas of mainland Portugal, in Mértola near Algarve and in Alandroal, southwest of Elvas (Dámaso Alonso, 1962, p. 39-40).

Similar phenomena are recorded in the speech of some of the islands in the Azores, mainly in the central group, Terceira, S. Jorge, Graciosa, and less extensively on the eastern and western groups, as well as in the speech of the islands of Madeira and Porto Santo. In addition, an important phonetic characteristic of the speech of Madeira is the formation of diphthongs as a result of the detachment of the glides [w] and [j].

Rogers (1946, p. 244-246) divides this development into two categories: a) the diphthong is formed independently of the vowels or consonants in contact; b) the diphthong results from the contact of the stressed vowel with the consonant. The consonants affecting the release of the glide are the velars $/ \mathrm{k} /$ or $/ \mathrm{g} /$, the bilabial consonants $/ \mathrm{p} \mathrm{b} \mathrm{m/,} \mathrm{or}$ /v/. Some examples: boc(u)ado, lug(u)ares, em c(i)asa, dorm(u)ir, sub(u)ir, p(u)ai, em b(i)aixo, v(u)ento. This type of diphthongization is also found in the speech of the island of Porto Santo (northeast of Madeira). Some examples: portug(u)eses, busc(u)ar, c(u)ais, lug(u)ar, dom(u)ingo (the / "/ is pronounced [öj]), $m(u) \hat{e}$, f(u)ilho (Rogers, 1948, p. 3). Other examples registered in Porto Santo also appear in the north of Portugal (Monteiro, 1948-50, p. 93).

b) Zone 2 is characterized by a profound alternation of the whole vocalic system, especially that of the stressed vowels. The most distinct feature of this Zone is the palatalization of /u/ as [ü] and Cintra (1983, p. 155) proposes its isogloss as the limit of dialect demarcation. ${ }^{13}$ There is also

\footnotetext{
${ }^{13}$ The palatalization of $/ \mathrm{u} /$ is frequently registered in some localities in Portalegre, Moção, Nisa (especially in this area), Castelo Branco, Idanha-a-Nova, Oleiros, Covilhã. In reference to the presence of [ü] in this region, Boléo (1969-71:875-76) informs that this vowel is found "do Minho ao Alentejo, e não apenas na Beira Baixa, como geralmente se supõe.”
} 
palatalization, to a lesser or greater degree, according to locality, of stressed /a/ when in contact with a consonant or a semivowel or when, in the preceding syllable, one of the vowels $i$ and $u$, or their glide counterparts is found. Some examples of this palatalization in this region, and also some cases registered in Algarve are identified when the syllable preceding the stressed /a/ has /i/ or /u/, or / ej/ or /ow/ as in the following words: buraco, aguilhada, giada, felicidade, cidade, vinagre, buraco, animal, buscar, ficar, fumar (Sabugal, Fundão, Sobral, Oleiros, Sertã, Bemquerença, Monsanto and Idanha-a-Nova), geada, alguidar, curral (Portalegre and Castelo Branco); or in barraca, amarelado, azulado, canastra in areas of Algarve (Dámaso Alonso, 1962, p. 150; Maia, 1975-78, p. 46; Boléo and Silva, 1961, p. 100). In other examples the palatalization of /a/ seems to be caused by the influence of the preceding palatal phoneme as in balhar, relampejar heard in Monsanto, Beira Baixa (Dámaso Alonso, 1962, p. 151), bacalhau, calhau registered in Algarve (Maia, 197578, p. 46). This palatalization is also recorded in the north, Minhoto, as in the words: buraco (also heard with [e]), embala, jarro (Santos Silva, 1961, p. 309). Boléo and Silva (1961) write:

uma linha vertical divide as zonas em que se verifica a passagem do $a$ oral a $e$, e a do $a$ nasal a $e$, correspondendo a zona ocidental à transformação sofrida pelo $a$ oral.

Cintra (1983, p. 133, note 28) disagrees with this delimitation of / a/ as $[\varepsilon]$ and he writes:

o traço 'geral' 5 do minhoto - aparecimento de e aberto, correspondendo a a tónico aberto do português-padrão, só nas palavras bacalheu e bureco (e por vezes em pestenas), e não, de um modo geral, nas palavras com a tónico aberto...é um fenómeno que se regista esporadicamente em regiões 
muito afastadas do Minho.

Dámaso Alonso (1962, p. 149-151), who has studied the speech of Valle of Ancares (north of León), has found the palatalization of stressed /a/ (as [ä] or as $[\varepsilon]$ ) in cases where the syllable before the stressed /a/ had either / $\mathrm{u} /$ or /i/ or the semi-vowels.

We have heard this phenomenon in some sporadic cases in the speech of Terceira (Azores), and a number of examples pertaining to the pronunciation of $/ \mathrm{a} /$ as $[\varepsilon]$ in this speech (Ribeirinha, S. Mateus) is also provided by Borba e Maia in her unpublished thesis presented at the University of Lisbon 1965 (p. 3-5). Moreover, there is labialization of /e/, and to some degree that of the diphthong /ow/. ${ }^{14}$

c) Zone 3 also palatalizes /u/ (Cintra, 1983, p. 157-158) as in Zone 2. The palatalization of $/ \mathrm{u} /$ in this region had already been noted by Leite de Vasconcelos (ed. 1970, p. 83). ${ }^{15}$ This geographic delimitation of the palatal /u/ is also reiterated by Cuesta and Mendes da Luz (1980, p. 61). Regarding the intensity of this vowel they conclude that "A palatalização do $u$ pode ser mais ou menos intensa e não se dá em posição átona: maduro (ü) mas madurar (u). Nunes (1902, p. 34) referred to a French [ü] in Vila do Bispo. Also registered here by Lüdtke (1957, p. 95-112) and Maia (1975-78, p. $58) .{ }^{16}$

As well, the stressed /a/ velarizes and is pronounced as [0] (as [0] in areas of the Algarve (Cintra, 1983, p. 158; Hammarström, 1953, p. $137-$ 9; 143 and passim; Lüdtke, 1957, p. 95-112; Cuesta and Mendes da Luz Cuesta, 1980, p. 62). In an attempt to explain the distribution of velar /a/, Hammarström says:

\footnotetext{
${ }^{14}$ As already Indicated, Lüdtke (1957:106-110) has studied the vowel system of this region, and he establishes two vocalic systems: one for the area Póvoa e Meadas and Montalvão, south of Tagus; and the other for the area of Castelo Branco and Idanha-a-Nova, south of Tagus.

${ }^{15}$ See above.

${ }^{16}$ For other references regarding the geographic delimitation of ü, see above.
} 
... nous avons eu parfois l'impression que c'étaient les personnes relativement jeunes qui possédaient les $a$ les plus vélaires. Faut-il y voir le signe d'une tendance qui va s'accentuant? (1953, p. 139)

In connection with this velarization let us also note that the stressed $/ \mathrm{e} /$, Standard Portuguese $[\mathrm{e}]$, tends to be pronounced with a velar timbre in the Algarve, and the nasal counterpart, may also have a back pronunciation, as [ã] or as [õ] in addition to its Standard pronunciation (Maia, 1975-78, p. 46-50; Hammarström, 1953, p. 53, 71).

In zone 1, speech of Minhoto, this nasal may also be velarized (Santos Silva, 1961, p. 311; Boléo and Silva, 1951, p. 94-95 and passim). Cintra (1983) finds this an important feature of minhoto speech, and he wrote:

... me parece difícil traçar com precisão o limite, conviria aludir ao carácter velarizado, e não apenas aberto, do ã nasal, e elimiar a referência à sua $<<$ semioralidade $>>$, que na realidade não me parece existir. (p. 133, note 28 )

Also in Minhoto this stressed nasal may be denasalised; or diphthongized and pronounced as either [õw] or [ãw] (Santos Silva, 1961, p. 311; Boléo and Silva, 1961, p. 96; Vasconcelos, 1970, p. 89) ${ }^{17}$.

The open /o/ closes to [o] (Cintra, 1983, p. 158; Hammarström, 1953, p. 51, 66, 70, 79, 144 and passim; Lüdtke, 1957, p. 95-112; Maia, 1975,

\footnotetext{
${ }^{17}$ This latter pronunciation is documented in Baixo Alentejo, and in the centre in Castelo Branco (Boléo and Santos Silva, 1951, p. 100, 102).

${ }^{18}$ This is heard in the western region of this province according to Hammarström and Lüdtke. Though Maia indicates that this trait is not unique to the west of Algarve but to the whole province of the Algarve, particularly in Alte and the centre of this province. She reports (note 1, p. 55) that some unpublished works, specially the thesis by Maria Luísa Segura da Cruz, "O falar de Odeleite," Faculdade de Letras Universidade de Lisboa, 1969, p. 27, do not share Hammarström's results, therefore [o] replaces the Standard Portuguese [0] in many areas outside those demarcated by Hammarström.
} 
p. 78-85). ${ }^{18}$ The closed /o/ closes farther and is pronounced as [u] (Cintra, 1983, p. 158; Hammarström, 1953, p. 51,144, and passim). ${ }^{19}$ The palatal vowels, on the other hand, also undergo changes: the /e/ opens and is pronounced as [ع] (in Sagres, Albufeira, Alvor, Lagos and Foia apud Cintra, 1983, p. 158; Hammarström, 1953, p. 47, 68 and passim; Lüdtke, 1957, p. 95-112; Boléo and Silva, 1961, p. 102). ${ }^{20}$ The open / $\varepsilon /$ has a very open timbre, tending toward [a]. Cintra (1983, p. 158). Viana (1883) described the pronunciation of $/ \varepsilon /$ as "un peu moins cependant que l'a bref anglais de bad, dans l'Algarve ou Beira Baixa, par example” (p. 167). ${ }^{21}$

\footnotetext{
${ }^{19}$ For the pronunciation of some nouns, in either plural or singular, Maia (1975-78, p. 55-57) indicates that the vocalic conditioning differs from that of Standard Portuguese. This is the case with either porco / porcos with [0] in both forms (as opposed to the Standard pronunciation as [porku] / [porkuJ], respectively). Maia (p. 56) remarks: “...são muito frequentes em toda a província formas com timbre fechado no singular e no plural. On the other hand, the nasal /o / occurs with a more open timbre than its Standard counterpart (Hammarström, 1953, p. 15859). In the eastern region of this province there is phonetic differenciation in the pronunciation of either plural or singular forms as in Standard Portuguese.

${ }^{20}$ Hammarström also noted /e/ with a very open timbre when before the palatal consonants, as in vejo, coelho, três, serrenho, tenho in Foia, Alte and Alvor (p. 73, 78, 97, 128-131). In northern speech, /e/ before these palatals (as in ovelha, orelha, abelha) may be pronounced as in Standard Portuguese, or as [ $\varepsilon j]$ (also heard in the island of Porto Santo apud Monteiro, 194850, p. 92), or as [ej] (Boléo and Silva, 1951, p. 96; Cuesta and Mendes da Luz, 1981, p. 65), and as $[\varepsilon]$ in other conditions (Boléo and Silva, 1961, p. 102). The nasal counterpart also opens in the speeches of Sagres, Silves, Foia, Monchique (Algarve in such words as tempo, dente, bem (Hammarström, 1953, p. 53, 80, 156); and it may also be pronounced as nasalised $[\mathrm{e}]$ in areas of Baixo-Alentejo and Algarve (Maia, 1975-78, p. 53-54; Boléo and Silva, 1962, p. 102). The latter pronunciation is also recorded in the northern speech (Boléo and Silva, 1961, p. 97-99).

${ }^{21}$ Also in the Algarve, Hammarström (1953) recorded / $\varepsilon /$, and with a more open timbre in Foia, Monchique, Lagos, Alvor, Silves, Albufeira and Santa Luzia, and as [æ] in Sagres and Alto (p. 48, 85, 89, 113, 133-134 and passim ). Maia (1975-78, p. 52) on the other hand, registered / $\varepsilon /$, as in delas, pesca, with a timbre of a vowel between [e] and [a], or as [æ] in Lagos, Vila do Bispo and Marmelete (Algarve), and she also notes that when syllable final, / $\varepsilon$ / may diphthongize as [عj], however, there is no diphthongization if “...-é final de palavra não é seguido de pausa no interior da cadeia fónica..: o vento 'tá' qui do pé da peguia;... pé de feijão ...” (Maia, 1975-78, p. $53)$.
}

SIGNUM: Estud. Ling., Londrina, n. 5, p. 77-106, dez. 2002 
Hammarström, who studied this speech, gives the following chain reaction: $\left(\right.$ ei $>$ e) $>\varepsilon>a>0>_{0}>\mathrm{u}>\ddot{\mathrm{u}}\left(\right.$ p. 160). ${ }^{22}$

A profound change in the vocalic system, with features similar to those noticed here is found in the speech of S. Miguel (Azores), and sporadically manifested in the speech of the other islands in the Azores: Flores, Corvo, Graciosa, Terceira, Pico and Santa Maria (Blayer, 1992). The palatalization of $/ \mathrm{u} /$, a prominent feature of the speech of São Miguel, is registered, though less extensively in the islands of Flores, Corvo, Graciosa, Santa Maria, Terceira, and Pico; and is found in Porto Santo and Madeira. Particularly in Machico and Porto-Moniz (Vasconcelos, 1970, p. 130), and on the "southern part of the island along the coast eastward from Câmara dos Lobos to Machico, including both of these places" (Rogers, 1946, p. 241-42). In this speech, [ü] is also heard when the stressed vowel is followed by /1/ as in desculpe, ultima (Rogers, 1946, p. 242). The Madeiran [ü] has been described as the Swedish /u/ (Viana, 1883, p. 34, note 2 to p. 33). Rogers (1946, p. 241) notes that this vowel is "slightly less

\footnotetext{
${ }^{22}$ The stressed /i/ has also been labialized (in pedidos, fitas) in Sagres and Faro, and compared to the Swedish /i/ (Hammarström, 1953, p. 47, 99, 126-127). Hammarströn describes the /i/ as follows: "Notons que notre impression auditive d'une voyelle labialisée est peu sûre, parce qu'il est possible de prononcer, sans arrondir les lèvres, un son très proche de l'y suédois: il s'agit sans doute d'une sorte d'i postérieur assez ouvert." Lüdtke (1952, p. 479) describes the /i/ of Loulé-Faro-Olhão as a central or velar unrounded vowel and "identique à l'i perçu par nous comme labialisé." Maia (1975-78, p. 54) has found in Vila do Bispo and Alte that the pronunciation of stressed /i/ "....algumas vezes, apresenta uma realização bastante aberta, dando a impressão acústica de uma vogal intermédia entre e e i."

In the speech of the island of Porto Santo (about twenty-seven miles northeast of Madeira) the stressed oral or nasal /i/ is often heard as oral or nasal [öj] as in bonito, meio dia, domingo, assim. (Rogers, 1948:2). In Madeiran speech, the stressed /i/ is also pronounced as the diphthong /oj/ and the first element appears to have a timbre "between i and ö" (Rogers 1946:239). Moreover, Rogers mentions that the pronunciation of the stressed /i/ is not consistent, not even when pronounced by the same individual, and he remarks as well that this phonetic trait is one of the "most striking features" of this speech (p. 240). Vasconcelos (1970:130) had already referred to the peculiarity of the Madeiran stressed /i/, and he noted: "Dans toute l'île de Madère, il y a un i spécial que M. Gonçalves Vianna (Essai de Phonétique, p. 6) compare à l'y polonais, et que je note par ï, ex. navio (presque navêio), rïo.”
} 
forward than the $\ddot{u}$ of German müde or the $u$ of French pur." Within the same areas where $/ \mathrm{u} /$ is heard as $[\ddot{u}]$, the nasal counterpart is also registered with a labialized timbre (Rogers, 1946, p. 242).

The back pronunciation of $/ \mathrm{a} /$, heard on all islands with various degrees of velarization (as [a], as [a] or as [o]), is heard as [å] in the insular speech of Porto Santo, and in Madeira its pronunciation ranges "from Standard $a$ almost to open 0 " (Rogers, 1946, p. 242). The pronunciation of $/ \mathrm{O} /$ as $[\mathrm{u}]$, widely heard on the speech of all Azorean islands, not just on S. Miguel is also a charatectistic of the speech of Madeira (Vasconcelos, 1970, p. 130; Rogers, 1946, p. 248).

\subsection{Vocalic Tendencies in the Speech of the Azores}

The vowel system of the speech of the Azores Islands has several important tendencies which are generally most prominent on São Miguel, and sporadically interspersed throughout the other islands. It is in São Miguel that the vocalic system has undergone the most advanced stage of development. The linguist, Leite de Vasconcelos (1925), who studied the speech of Arrifes in São Miguel remarked:

O dialecto dos Arrifes, no concelho de Ponta Delgada, representa a fase mais evolucionada, que conheço, do português, com excepção dos crioulos, como o dialecto de Melgaço é o mais arcaico de todos. (p. 49)

As we know today, it is not only the speech of this area that differs from the Standard language, but that of São Miguel as whole. This speech has the fronted palatals / ̈̈/ and / $/$ /. Its front members have opened and the center and back members show closing as well as some of the palatalization in an overall chain reaction. Most interesting, the spoken language displays in the articulation of the vowels an array of variety which unables us to see the intermediate stages that take place. The western 
group of islands (as well as sporadic examples collected in other islands) also have /ü/ and /ö/, but otherwise their system has not fully developed and it has not reached the degree of evolution that exists in São Miguel.

The change affecting the vocalic system of São Miguel, somewhat parallel to that of mainland zone 2 as identified by Lüdtke, may be schematized as follows:

$($ ei $/$ eu $>$ e $>\ddot{o})$ e $>\varepsilon>a>o(>\propto / \ddot{o})>(o i / o u>o>\ddot{o}) o>$ u $>\ddot{u}^{23}$

An analysis of vowel fronting for the other islands ${ }^{24}$ shows that the change affecting asymmetry of the vocalic systems ${ }^{25}$ of the insular speeches involve the following patterns: ${ }^{26}$

I. The conversion of falling diphthongs to monophthongs and then

\footnotetext{
${ }^{23}$ Some phonological characteristics of the speech of the island of São Miguel, such as the presence of the palatal vowels / $\ddot{\mathrm{u}} /$ and /ö/, have been ascribed to Celtic influence. As we saw above, similar traits are clearly apparent in other speeches (Corvo, Flores, Sta. Maria and the Central islands). However, it is at its most advanced in São Miguel. There are some interesting parallels between the vowel system of São Miguel (including the presence of / ̈̈/ and /ö/), and that of some regional variants of Portuguese. It is very easy, of course, to think of the influence of early settlement from regions of Portugal where the system is prevalent. This cannot be excluded, but it is better not to be categorical as one has little knowledge of the history of these developments, or of the antiquity that these have on the Continent. We are still far from being able to explain why Portuguese varieties (such as the speech of São Miguel) have the characteristics that they do. Based on the evidence that we have (in particular that we see all different stages that lead to the formation of the system of São Miguel, and also the mixed stages in the vocalic system of other islands), it seems reasonable to claim that what had been attributed to Celtic influence may actually indicate that we are dealing with the internal evolution of the language.

${ }^{24} \mathrm{I}$ am not delimiting the vocalic sound system for the entire insular speeches, but referring to specific speech areas as detailed in Blayer (1992).

${ }^{25}$ The nasal vowels counterparts will not be included here.

${ }^{26}$ This is a simplified view of the vocalic changes taking place in these speech areas. For a detailed analysis see Blayer (1992).
} 
levelled to the rounded fronted vowels:
a. (ei / eu ) > e > ö (Corvo, Flores, Graciosa, Santa Maria, São Miguel).

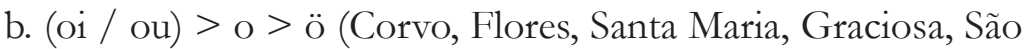 Miguel).
c. ui $>$ ü (Flores, Corvo, São Miguel).

II. The second wave of vowel development applies to the necessary condition for the fronting of regular context-free vowels - high and mid-back, or mid-high fronted vowels-:
a. e > ö (Corvo, Flores, São Miguel -from monophthongization).
b. o $>\ddot{o}$ (Corvo, Flores, Santa Maria, São Miguel also resulting
from monophthongization).
c. u > ü (Flores, Corvo, Graciosa, Santa Maria, Pico, São Miguel).
d. ○> / ö (São Miguel).

The developments recorded in S. Miguel agree in part with those presented by Martinet (1955). Martinet's account of the phonological changes in the speech of São Miguel are based on Rogers' article (1948). It must be emphasized, however, that today we have more data which provide a more clearer idea of the changes taking place in the vowel system of this island.

Parallel developments, especially the fronting of mid and high-back or mid-high fronted vowels can also be described as part of the tendencies affecting some speech areas of Peninsular Portuguese, as discusses above.

A further comparison of the speech of São Miguel with that of the other islands produces other important parallels, but overall these do not profoundly affect the vocalic system, as it occurs in São Miguel, since they appear to be at a beginning or intermediate stage. Some developments may be cathegorized as follows: (a) labialization of the stressed velar back 
vowels, as well as the mid fronted /e/; (b) As we indicated above, the stressed /a/ velarizes in the speech of S. Miguel, and is pronounced as [0] or with intermediate stages between [a] and [a]. Similar pronunciation generally occurs in the speech of all the other islands. ${ }^{27}$ The opening also affects the front vowels /e/ and $/ \varepsilon /$.

Finally, an important feature which distinguishes the speech of the Central group -Terceira, São Jorge, Pico and Fayal- is the release of the glides [w] or [j] before stressed vowels, and this diphthongisation is, according to our research and also Rogers' study (1949, p. 49) and Maia's thesis (1965), a general characteristic of the speech of Terceira. The other groups (Eastern and Western) also have sporadic cases of this diphthongisation. The release of $[\mathrm{w}]$ occurs after any consonant. It appears, due to the number of the examples, that it was common after the bilabials $/ \mathrm{p} \mathrm{b} \mathrm{m} /$, and the velars $/ \mathrm{kg} /$, and it may have begun with this context and afterwards it spread in contact with other consonants such as the

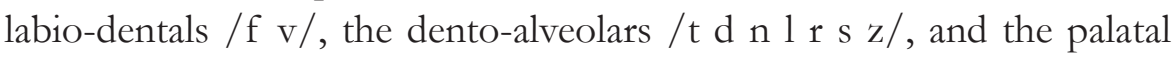
$/ K /{ }^{28}$ The release of [j] occurs in particular after the dento alveolars $/ \mathrm{t} \mathrm{d} \mathrm{n} 1 \mathrm{r} \mathrm{s} \mathrm{z} /$, the bilabials $/ \mathrm{p} \mathrm{b} \mathrm{m} /$, the velars $/ \mathrm{kg} /$, the palatals $/ \Lambda$ ? $\mathrm{n} /$, and the labio-dental $/ \mathrm{v} /$. It is also registered after the consonantal groups tr, br, gr. ${ }^{29}$

\section{Concluding Remarks}

Looking at these speeches synchronically, it appears that some of the vocalic tendencies featured in the speeches of the regional varieties in mainland Portuguese are clearly apparent in the insular speeches of the

\footnotetext{
${ }^{27}$ See Blayer (1992).

${ }^{28}$ For details see Blayer (1992).

${ }^{29}$ For details see Blayer (1992).
} 
Azores and the Madeira islands. There are some interesting parallels between these vowel systems.

Based on the evidence that we have, in particular the finding that we see all stages that lead to the formation of the system of São Miguel (Azores) as well as in the southern continental Portuguese-zone 2 and 3 - and all mixed stages in the vocalic system of the various regions in the insular and continental speeches, it seems reasonable to claim that we are dealing with a Romance phenomenon which clearly deserves careful analytical examination in future research in this area. The challenge is of course to extend the study to a detailed and refined analysis of phonological environments conditioning the sound change.

\section{References}

AGARD, F. B. A Course in Romance Linguistics, 2 Vols. Washington: Georgetown University Press, 1984.

ALONSO, Dámaso. La Fragmentación Fonética Peninsular. Vol. I of Enciclopedia Lingüistica Hispánica. Madrid: Consejo Superior de Investigaciones Científicas, 1962. 216.

ARRUDA, Velho. Colecção de documentos relativos ao descobrimento e povoamento dos Açores. $2^{\text {nd }}$ ed. Ponta Delgada: Instituto Cultural de Ponta Delgada, 1977.

BAPTISTA, Maria de Fátima Ferreira. "Ilha do Faial (Açores): Contribuição para o estudo da sua linguagem, etnografia e folclore." Diss. Coimbra, 1970.

BICKERTON, D. Roots of Language. Ann Arbor:Koroma, 1981.

BLAYER, Irene Maria F. Aspects of the Vocalic System in the Speech of the Azores Islands. Ph.D. Diss. University of Toronto, 1992.

BOLÉO, Manuel de Paiva. "A Língua Portuguesa do Continente, dos 
Açores e do Brasil (Problemas de Colonização e Povoamento)." Revista Portuguesa de Filologia 18 (1983):591-625.

.Alcuni problemi del paesaggio dialettale portoghese specialmente della parlata meridionale." Estudos de Lingüistica Portuguesa e Românica 1 (1975):400-32.

"Brasileirismos (Problemas de Método)." Brasilia III (1943):

$2-82$.

"Dialectologia e história da língua. Isoglossas portuguesas." Boletim de Filologia XII (1951): 1-44.

."Unidade e variedade da Língua Portuguesa." Revista da Faculdade de Letras de Lisboa XX (1954): 5-28.

"Alcuni problemi del paesaggio dialettale portoghese specialmente della parlata meridionale." Estudos de linguistica portuguesa e românica I (1975): 400-432.

BOLÉO, Manuel de Paiva, and Maria Helena Santos Silva. "O Mapa dos Dialectos e Falares de Portugal Continental.” Boletim de Filologia XX (1961): $85-112$

BONAPARTE, Louis Lucien. "On Portuguese Simple Sounds, Compared with those of Spanish, Italian, French, English, etc." Transactions of the Philological Society I (1880): 23-41.

"Portuguese Vowels, According to Mr. R. G. Viana, Mr. H. Sweet, and Myself." Transactions of the Philological Society III (1885): 404408.

BORGES, Nair Odette da Câmara. "Holmer, "Dialecto de S. Miguel"." Rev. of Algumas observações sobre o dialecto português de São Miguel (Açores), by Nils M. Holmer. Revista Portuguesa de Filologia X (1960) 331-335.

. "Influência anglo-americana no falar da ilha de S. Miguel (Açores)." Revista Portuguesa de Filologia Supplement II (1960): 6-67. 
BOURCIEZ, Edouard. Eléments de Linguistique Romane. PariS: Klincksieck, 1910.

BRUMMER, Fred. "Survival of American Whaling Terms in the Azores," American Speech, XXXV (1960):20-23.

CARVALHO, José Herculano de . "Porque se falam dialectos leoneses em terras de Miranda?” Revista Portuguesa de Filologia V (1952): 265-291.

CUESTA, Pilar V. And Maria Albertina Mendes da Luz. Gramática da Lingua Portuguesa. Edições 70, 1980.

COSERIU, Eugenio. 'Los conceptos de 'dialecto', 'nivel' y 'estilo de lengua' y el sentido propio de la dialectologia.” Sep. Linguística Española Actual III (1981): 1-32.

CUNHA, Celso, and Lindley Cintra. Nova Gramática do Português Contemporáneo. 2nd. ed. Lisboa: Edições João Sá da Costa, 1984.

DIAS, Maria Alice Borba. Ilha Terceira: Estudos de linguagem e etnografia. Angra do Heroísmo: Secretaria Regional de Educação e Cultura, Direcção Regional dos Assuntos Sociais, 1982

FURLAND, Oswaldo António. Influência Açoriana no Português do Brasil. em Santa Catarina. Florianópolis : Editora da Universidade Federal de Santa Catarina, 1989.

GONÇALVES VIANA, Aniceto dos Reis. "Essai de phonétique et de phonologie de la langue portugaise d'après le dialecte actuel de Lisbonne." Romania 12 (1883):2998. Rtp. In Boletim de Filologia 7 (1941):161-243.

. "Portugais." Le Maître phonétique. 1889: 79-80.

- "Exposição da pronuncia normal portuguesa para uso de nacionais e estrangeiros." Luis de Camões, Os Lusíadas, Canto I,. Ed. F. de Salles de Lencastre. Lisbon: 1892.

Portugais. Phonétique et phonologie. Morphologie. Textes. Leipzig: 1903.

SIGNUM: Estud. Ling., Londrina, n. 5, p. 77-106, dez. 2002 
- Ortografia Nacional. Simplificação e uniformização sistemática das ortografias portuguesas. Lisbon: 1904.

GUIMARÃES, Joaquim de José Oliveira. Fonética Portuguesa. Compêndio da ortologia nacional. Trabalho Fonético da Faculdade de Letras. Coimbra, 1927.

HALL, Robert A., Jr. External History of the Romance Languages. New York: Elsevier, 1974.

HAMMARSTRÖM, Göran. Étude de phonétique auditive sur les parlers de l'Algarve. Uppsala: Almquist and Wiksells, 1953.

HARRIS, M. and Vincent N., eds. The Romance Languages. London: Croomhelm, 1988.

HAUDRICOURT, A. G. and Juillard A. Essai pour une bistoire structurale du phonétisme français. Paris: Klincksiek, 1949.

HECULANO DE CARVALHO, José G. "Porque se falam dialectos leoneses em terras de Miranda." Revista Portuguesa de Filologia (1952): 265291.

. "Os estudos dialectológicos em Portugal nos últimos vinte anos.” Revista Portuguesa de Filologia XI (1961): 307-321.

. "Nota sobre o vocalismo antigo português: valor dos grafemas e e o em sílaba átona.” Revista Portuguesa de Filologia XII, i (1962): 17-39

HERMAN, J., ed. Du latin aux langues romanes : études de linguistique historique. Jübingen: Niemeye, 1990.

LEITE DE VASCONCELOS, José. Esquisse d'une dialectologie portugaise. $2^{\text {nd }}$ ed. Lisbon: Centro de Estudos Filológicos, 1970.

- Mês de Sonho: Conspecto de etnografia açórica. Discurso pronunciado na Academia das Sciencias em 1 de Maio de 1925 e ora trazido a lume com extenso Apêndice. Lisboa, 1926. 
- "Dialectos Açoreanos (Contribuição para o estudo da Dialectologia Portuguesa)." Revista Lusitana 2 (1890-92):289-307.

. Mapa Dialectológico do Continente Português. Lisboa, 1897.

. Estudos de Philologia Mirandesa. Lisboa, 1900-1901.

LINDLEY, Cintra L. Estudos de Dialectologia Portuguesa. Lisboa: Sá da Costa Editora, 1983.

."Enquêtes au Portugal pour l'Atlas Linguistique de la Péninsule Ibérique.” Orbis III (1954): 417-418.

LÜDTKE, Helmut. “Fonemática Portuguesa, I: Consonantismo.” Boletim de Filologia XIII (1952): 273-288.

. "Fonemática Portuguesa, II: Vocalismo." Boletim de Filologia XIV (1953): 197-217.

. "Beiträge zur Lautlehre portugiesischer Mundarten." Miscelánea Homenaje a André Martinet: Estructuralismo e bistoria 1, ed. Diego Catalán. La Laguna: Univ. de la Laguna, (1957): 95-112.

MAIA, Clarinda A. "Os falares do Algarve." Revista Portuguesa de Filologia. 17 (1975-78):37-171.

MAIA, Maria Lúcia Borba e. "O falar da ilha Terceira.” Diss. University of Lisboa, 1965.

MARTINET, André. Économie des changements phonétiques. Traité de phonologie diachronique. Berne: Francke S. A., 1955.

MATEUS, Maria Helena Mira. Aspectos da Fonologia Portuguesa. Lisbon: Instituto de Investigação Científica, 1982.

MATOS, Lygia Maria da Câmara Almeida. Ilha de S. Miguel, seu dialecto e literatura popular. Ponta Delgada, 1936.

SIGNUM: Estud. Ling., Londrina, n. 5, p. 77-106, dez. 2002 103 
MATTOSO Câmara, José. "Para o Estudo da Fonêmica Portuguesa: Os Fonêmas em Português." Boletim de Filologia III.Rio de Janeiro (1949): 130.

. Para o Estudo da Fonêmica Portuguesa. Rio de Janeiro: 1953.

."Gonçalves Viana and the Phonic Sciences." For Roman Jakobson:

Essays on the occasion of his sixtieth birthday. Ed. Morris Halle et al. The Hague: 1956. 328-331.

Medeiros, Maria de Jesus Chichorro. "A linguagem micaelense em alguns dos seus aspectos." Diss. University of Lisbon, 1964

MORAIS-BARBOSA, Jorge. Les voyelles nasales portugaises: interprétation phonologique. Fourth International Congress of Phonetic Sciences. Helsinki: The Hague, 1961. 691-708. de Évora, 1983.

Etudes de phonologie portugaise. 2 ed. Évora: Universidade NUNES, José Joaquim. Compêndio de Gramática Histórica Portuguesa (Fonética e Morfologia). 8th ed. Porto: Livraria Clássica Editora, 1975.

PINTO, Adelina Angélica. "Isoléxicas portuguesas. (Antigas medidas de capacidade)." Diss. Revista Portuguesa de Filologia 18, 1983.

POSNER, Rebecca. The Romance Languages. Great Britain: Cambridge University Press, 1996.

POSNER, Rebecca and John Green. Eds. Trends in Romance Linguistics and Philology. Vol. 1. Mouton: The Hague. Paris, New York, 1980.

REDENBARGER, Wayne. "Lusitanian Portuguese $[\mathrm{e}]$ as an advanced tongue root and constricted pharynx vowel." Studies in Romance Linguistics. Ed. Peter Hagiwara. Rowley, Massachusetts: Newbury House, 1977.

- Articulator Features and Portuguese Vowel Height. Cambridge, Massachusetts: Department of Romance Languages and Literatures of Harvard University, 1981. 
ROGERS, Francis Millet. Rev. of Étude de phonétique auditive sur les parlers de l'Algarve, by Göran Hammarström. Romance Philology 8-9 (1954-56):28499 .

. "Insular Portuguese Pronunciation: Alleged Breton Influence" Romance Philology 2 (1949):305-314.

- "Insular Portuguese Pronunciation: Central and Western Azores." Hispanic Review XVII (1949): 1-32.

. "Insular Portuguese Pronunciation: Alleged Flemish Influence" in Mediaeval Studies in Honour of J. D. M. Ford (1948):211-221.

. "Insular Portuguese Pronunciation: Porto Santo and Eastern Azores." Hispanic Review XVI (1948): 1-32.

"Brazil and the Azores." Rev. of Brasileirismos (Problemas de Método), by Manuel de Paiva Boléo. Modern Language Notes LXII.6 June 1947: 361-370.

6 (1947): 361-370.

"Brazil and the Azores." Modern Languages Notes LXII.Number . "Insular Portuguese Pronunciation: Madeira." Hispanic Review 14 (1946):235-53.

. "Gonçalves Viana and the study of Portuguese phonetics." Boletim de Filologia I (1940): 7-13.

. "The Pronunciation of the Madeira and Azores Dialects as Compared with Standard Portuguese.” Diss. Harvard, 1940.

SILVA, Maria Helena Santos. "Características do falar Minhoto." Boletim de Filologia XX (1961): 309-321.

SPENCE, N. C. W. "Quantity and Quality in the Vowel-System of Vulgar Latin" in Readings in Romance Linguistics. Ed. James M. Andersen and J. Greore. Mouton: The Hague, 1972. 
SWEET, Henry. A Primer of Phonetics. Oxford: Clarendon Press, 1906.

TEYSSIER, Paul. Histoire de la langue Portugaise. Que sais-je. Paris: Presses Universitaires de France, 1980

WARTBURG, von Walther. La fragmentación lingüistica de la Romania. $2^{\text {nd }}$ edition. Madrid: Editorial Gredos, 1971.

WEINREICH, Uriel. "Is a structural dialectology possible?", Word 10:388-400. [Cited from rpt. in H.B. Allen and G. N. Underwood, eds., (1971), Readings in American Dialectology. Appleton-Century-Crofts, New York. [p. 300-313.] 